\title{
The Emergence of New African "Trading Posts" in Hong Kong and Guangzhou
}

\section{Brigitte Bertoncelo et Sylvie Bredeloup}

\section{(2) OpenEdition}

12 Journals

Édition électronique

URL : http://journals.openedition.org/chinaperspectives/1363

DOI : 10.4000/chinaperspectives. 1363

ISSN : 1996-4617

Éditeur

Centre d'étude français sur la Chine contemporaine

\section{Édition imprimée}

Date de publication : 15 janvier 2007

ISSN : 2070-3449

Référence électronique

Brigitte Bertoncelo et Sylvie Bredeloup, "The Emergence of New African "Trading Posts" in Hong Kong and Guangzhou », China Perspectives [En ligne], 2007/1 | 2007, mis en ligne le 08 avril 2008, consulté le 28 octobre 2019. URL : http://journals.openedition.org/chinaperspectives/1363; DOI : 10.4000/ chinaperspectives. 1363 
(

The emergence of new African "trading posts" in Hong Kong and Guangzhou BRIGITTE BERTONCELLO AND SYLVIE BREDELOUP

At a time when China is strengthening its economic ties with African countries both by sourcing raw materials and tapping a large consumer goods market, African traders are expanding their presence in China. Making the most of the conditions offered by the authorities, they have opened trading posts in Hong Kong and Guangzhou in order to sell products manufactured elsewhere in China for African customers. These traders are at the forefront of a new migration wave. This article analyses their profiles and itineraries before exploring their impact on the transformation of two specific locations: Chunking Mansions in Tsim Sha Tsui, Hong Kong, and the Xiao Beilu area in Guangzhou.

$\mathrm{A}$ $\mathrm{t}$ a time when China and Africa are intensifying their diplomatic and economic ties, a number of academic works have taken an interest in these exchanges (Coussy, 1999; Hoffmann, Mabire, 2000; Niquet, 2002; Aicardi de Saint-Paul, 2004; Braud, 2005; Lafargue, 2005; Chaponnière, 2006; Gaye, 2006). Other analyses have focused at another level on the role of Chinese merchants in the economic development of Namibia (Dobler, 2005), Cameroon (Esoh, 2005), Cape Verde (Haugen, Carling, 2005) and Madagascar (FournetGuérin, 2006) as well as on the socio-spatial restructuring triggered by their establishment in the host country (Bertoncello, Bredeloup, 2006). If this Chinese migration to the African continent again calls into question on a global scale the capacity of host societies to integrate within them new foreign populations, it can conversely be asked to what extent the movements of African merchants, most recently spotted between Hong Kong and Guangzhou, provide a lesson on the real capacities of opening up so frequently proclaimed by the People's Republic of China. It is, undoubtedly, equally appropriate to examine the commercial forms of the African settlements established in China, which are reminiscent of those of the Greek trading colony (emporium), that organisation, created on the initiative of the foreigner the colonist , that was founded on an understanding between producers and vendors and the functioning of which was very closely tied to the hinterland or took place in a foreign enclave (Tarrius, 1995).

Although the Chinese authorities praise the long-term relationship and friendship between their country and the African continent, the exchanges between these two areas, while certainly of old standing, have nevertheless remained unequal and above all built on power relationships in which China dominates. While Chinese power, through its public corporations, is exerted in these days of aggravated competition to purchase raw materials in energy and minerals across the whole of the African continent, small Chinese entrepreneurs old rural migrants or workers made redundant by state-owned factories, but also labourers recently laid off from construction sites in Africa are opening shops offering a variety of goods in Dakar, Praia, Bamako or Douala, renewing the forms of Chinese commercial migration. For their part, Africans, on the look-out for new markets, are restructuring the channels of distribution, leaving home to source supplies directly from Asia while still others settle there.

Once the different types of migrants present in China have been identified, the next question is to locate the respective place held by Asian cities in the migratory and commercial routes of the nationals from sub-Saharan Africa, then to examine the role that they play in the transformation of the urban zones thus endowed (Chungking Mansions, a highly 

sheep hides collected raw in Togo and then tanned in China. But Mr L preferred to get out of this lucrative activity when Chinese businessmen, inspired by his experience, began to compete with him on a permanent basis by directly setting up a modern tannery in Nigeria. He then changed direction, striking out into the textile sector and contracting a solid agreement with a factory located in Shenzhen's economic zone, even going so far as to take shares in the company.

At the office, the client chooses the fabric, the colour and the quality from samples, then it is made up for him. To go to the factory, you take the boat; it takes two hours, by boat. 1,900 workers work in this factory. It's exported 100,000 pieces for Angola (...) (1).

A section of his clientele does not travel as far as Hong Kong to place their orders for his goods, preferring to select and order them from his African offices hived off in Lomé and Nairobi. Mr L organises the transport logistics chain, also conducting the customs clearance of the goods for his clients. He is the archetype of the international trader, reinvesting as much in China (taking a stake in the capital of a factory set up in mainland China, owning a guesthouse in Chungking Mansions and managing an African restaurant), as in Africa (owning houses in Lomé, Abidjan and Dakar, and buildings and a commercial centre in Bamako).

His compatriot, $\mathrm{Mr} \mathrm{D}$, similarly hailing from the Kayes region and established in Guangzhou since 2000, presents a similar itinerary. He has also moved around a great deal in Africa, hawking cigarettes in the streets of Bamako when he was growing up before launching himself into the ready-towear business in Cameroon and Gabon and the traffic in precious stones from Tanzania and Madagascar. At the time of this perilous trade for the African diamond merchants, he learned the import-export business: in the producer countries, precious stones are rarely exchanged for money and are instead bartered for different goods, at the whim of circumstance. As for Mr D's establishment in China, this was facilitated by his previous experience in the import-export business at trading posts in Thailand and then in Indonesia. Taking advantage of the Canton Fair ${ }^{(2)}$, he came to prospect the region in 1998, wishing to profit from the commercial opening-up of China to find an opportune new direction for his business. Although importing by Africans is not authorised in China, $\mathrm{Mr} \mathrm{D}$ nevertheless decided to set up shop in Guangzhou in 2000, convinced that his clientele would fol- low him and that his trading would only expand. While he has closed his offices in Jakarta and Bangkok, he has kept open those in Lomé and Dar Es-Salaam to ground his presence on the African continent. Today, Mr D is considered to be Guangzhou's major West African merchant, exporting a multitude of manufactured products, from electric toothbrushes to DVD drives and plastic sandals, Arcopal tableware, imitation African pagnes (wrap-skirts), made in China, even green tea:

\section{When an African, American or European client arrives at my company, he can see the clothing sam- ples, hardware samples and samples of household appliances, and he can then choose. In my office, we discuss the quantity, the order and the price, and when we have come to an agreement, I call my dif- ferent suppliers, who deliver to me directly from the factory to a lead time that $I$ also negotiate. The orders, it's often several dozen containers each time.}

Mr D employs around fifty Chinese in his vast enterprise, where he takes care of the product from its manufacture to its export:

Here I have an office of 250 square metres and I am the tenant and I pay the taxes. I also have an apartment nearby in another building. For the office, I have 12 Chinese employees; and then for the interpreters, who are paid 500 yuan a day, I go through recruitment agencies. The interpreters speak English for the most part and some of them speak French. Me, I have three Chinese secretaries who speak a little French; the majority of our clients are French speakers. They are trained at the Alliance Française. People say afterwards: 'At D's, they speak French.' It's better! I also rent 6,000 square metres of warehouse space in the port zone and there I have 30 Chinese workers ${ }^{(3)}$.

Mr D's involvement in the production of goods exported to Africa has been strengthened over the years and should soon extend to his home country:

1. Interview with S.L., op. cit..

2. The international Canton Fair takes place twice a year (in April and October); it is one of the biggest fairs in the world, at which are traded textiles and electronics among many other products (Jastrabsky, 2006).

3. Interview with D.D., Malian merchant, Guangzhou, July 10 th 2006. 
I work with Chinese factories. There, I'm preparing to set up small factories in China and factories in Africa, in Mali.

$\mathrm{Mr} \mathrm{D}$ is planning to consolidate his investments in Bamako:

I have got in contact with the ACI [Agence de Cessions Immobilières], that is the state agency that handles land in Mali and I have asked them to find me a site with a project for a commercial centre. Because we travel, we take a few ideas from abroad and we bring them back home. The commercial centres there, it's good. You can also do some offices on top, but you can't have too many storeys, Africans don't like that much. As for my country, I've also thought about buying some agricultural machines for the crops but in places where the growing is good.

$\mathrm{Mr} \mathrm{D}$ can also draw value from his experience as an economic operator in China in dealings with the Malian authorities in charge of managing the Diaspora. That is how he came to play an active part in the deliberations related to the creation of a banking structure intended for migrant investors.

I signed a protocol in 2004 with the Mali ministry of investment to create an "overseas Malian bank". If this project takes concrete shape, I will go and canvass in France, everywhere where there are Malians. (...) At the next elections, I am standing as a candidate for the presidency of the Haut Conseil des Maliens de l'Extérieur [official body responsible for relations with Malians living abroad]. Mali pays attention to its migrants. In 2004, the Malian president came here at our invitation. Look, I have a traveller's customs guide which has been published by my country. Our country supports its Diaspora. The current president of the Haut Conseil isn't a merchant, he doesn't know the problems Malians have everywhere in the world. This time, there are two serious candidates, there should be some good progress.

Similar to the consortia involved globally in the retailing and distribution industry, the African traders who have set up shop in Asia have the ability to link the centres of production to the markets. Not only are they redrawing the trading routes, but, what's more, they are contributing to the creation of new products for an African clientele while negotiating directly with the Chinese factories and increasingly taking control of the transport logistics chain. Moreover, the system of information that they have put in place at the international level allows them to keep in direct touch with the needs of the consumers and to respond rapidly to them. Their economic and social success can also be explained in part by the relations they have been able to weave here and there with the state powers. Back at the beginning of the 1990s, E. Grégoire and P. Labazée studied these forms of co-operation between the political and commercial spheres but limited themselves to the African continent. The big African merchants who have set up shop in the strongly Asian locations have been able to negotiate their place in these societies, playing the role of an interface between their communities and the local society, a role which has allowed them to consolidate their status as economic operators. These businessmen have thus made an extensive contribution to the construction of these African trading posts in Asia.

As for the young traders who are also taking part in the consolidation of these trading places, the majority of them have pursued higher studies outside of their own country, before launching out into international trade. $\mathrm{Mr} \mathrm{A}$, a Ghanaian, who opted to take a journalism course in Great Britain and then in Holland, chose for political reasons to change direction and take up commercial activities after having practised for some time only in his own country. $\mathrm{Mr} \mathrm{B}$, for his part, a native of Futa Djalon in Guinea, left for New York in 1989 to pursue a higher education course in information technology. Convinced that he would not be able to draw full value from his engineering degree in Guinea because of the economic and political insecurity that reigned there, he chose to form a company in the United States for the export of computer equipment, benefiting both from social capital and technical abilities as well as economic capital thanks to the support of an older brother who had emigrated to the Congo:

I sell computer equipment bought here in China to American clients, clients from the Caribbean; Africans in the USA as well. I work by e-mail, by fax and by telephone; I also go on trips, I have an office down there. In fact, I started to-ing and fro-ing between New York and Guangzhou in 2002. The first time, I came here for two months [December 2002 to January 2003] and then I went back; after- 
wards I did a trip in March and then another in August. That began to last longer and I set up shop here. Now, I'm more here than I am in New York ${ }^{(4)}$.

To diversify his activities and to get a foothold on the African market, he decided to export electrical generators made in China to Angola. Very quickly, African competitors entered this high-growth market niche, offering lower rates than his but, according to him, for products of inferior quality:

I have always had loyal relations with my suppliers. At a certain moment, I could no longer sell generators in Angola. Loads of new African merchants came on the scene with very cheap Chinese generators (...) but of very poor quality. I took a step back, I didn't change anything, I waited; the next moment, the buyers came back to the quality ${ }^{(5)}$.

The relations of trust that the traders manage to contract with their suppliers seem effectively to determine the success of their enterprise. Some highlight African solidarity to counter the disloyal competition.

The clientele of the traders remains predominantly African and male; it is composed both of "circulating merchants", consolidating the shuttle between the Asian trading posts (Bangkok, Hong Kong, Guangzhou) and the African markets, and of businesspeople placing their orders directly from their companies situated in Africa, Europe or the United States. These latter have become acquainted with the range of products offered by the traders, either during an initial prospecting trip or from the networks set up by these same traders in several African countries. For these different clients, the traders generally take care of the transport and transit operations and the customs clearance of the purchased goods. A feminisation of the profession can nevertheless be seen. Located just as much in Paris, Marseille and Naples as in Bamako, Conakry, Abidjan, Cotonou or even Lusaka and Dar es Saalam, these female African merchants are in fact forsaking in ever greater numbers the trading post of Dubai to come and find their supplies on the Asian markets. A lady from Zambia, dressed in pagne fabrics, waits in front of the Western Union counter on the ground floor of Chungking Mansions in Hong Kong. She is relating how she is reckoning on consolidating and sending goods from the port of Luanda in Angola to Lusaka, the Zambian capital. Two ladies from Tanzania encountered on the Hong Kong-Guangzhou train ${ }^{(6)}$, of a very Westernised appearance (denim jeans and shirts, stiletto heels and straightened hair), were finishing their "circuit" having made their first purchases in Paris and in Italy the previous week. Accompanied by a Chinese translator, a Kenyan lady, a recent graduate in business management, comes to join a group of traders and West African nomadic merchants sat at a table in a café in a tower of Tianxiu Building in Guangzhou. She is making her debut in the profession; this is her first trip to China. Enthusiastic, very confident of the future, she is already planning her next stay. On the upper floors of the building, in the offices of the African traders, ladies from Guinea and Mali come every two months to negotiate; handbags one time, imitation wax $^{(7)}$ the next.

Students, traders, nomadic merchants but also sportsmen: the Africans play off these different status to establish their position in Asia as they have done elsewhere. Nigerian students who have failed the university courses they have begun in Guangzhou prefer to stay in the city rather than return home, and they then start out down the commercial route. Others, like Mr D, who have completed their higher studies in Nigeria but have no immediate prospects of employment there, have chosen to migrate. After running his eye over the conditions for obtaining a visa in Asia and in Europe, D spotted during his research that China offered opportunities. Once he had arrived on Chinese territory, Mr D tried to make use not of his degrees and diplomas but of his sporting ability. He initially played football for a second division club and is now coaching a young team in a district of Guangzhou. ${ }^{(8)}$ Old nomadic merchants convert back to being traders after a few years' activity. Or, conversely, traders abandon their offices; preferring to limit their fixed costs, they launch themselves back into the itinerant trade. Still others, taking $\mathrm{Mr} \mathrm{L}$ as an example, will from now on take care of their business in the cafés of the tower blocks in the district of Xiao Beilu rather than in offices. Having been involved in an environmental survey that led him to Korea

4. Interview with H.B., Guinean merchant, Guangzhou, July 9th 2006.

5. Interview with H.B., Guangzhou, July 11 th 2006.

6. Guangzhou is linked to the station in Kowloon in Hong Kong by express train (182km in two hours). The building of a new international airport at Baiyun in August 2004 should rapidly change the routes taken by the African merchants. This airport, which serves the cities frequented by the African traders (Dubai, Bangkok, Jakarta, Nairobi, Addis Ababa, etc.), is supposed to become a direct competitor with Hong Kong's international airport.

7. An African fabric made of quality printed cotton manufactured in Dutch and English factories to be sold primarily on the African markets. These waxes have gradually faced competition from fabrics produced in factories set up in Africa within the framework of an economic policy of import substitution.

8. Interview with C.D., Nigerian sportsman, Guangzhou, July 12 th 2006. 
and having taken a new direction with studies in e-marketing in London, this former physics and chemistry professor from Togo started out on a commercial career. He set up a trading post first of all in Kuala Lumpur (Malaysia) in 2001 and then in Guangzhou in 2003. He has just closed his offices and is counting on his reputation to establish and maintain contact with his clientele using his single mobile phone. A new category of trader based on circulation has thus been introduced for the same reason as that of the tout-interpreter:

It is necessary to distinguish between those who have an office, those who come to buy and those who don't have an office but are looking for a clientele, and those who don't have offices. There are touts; these are youngsters who speak Chinese well; us, we have offices, with Chinese secretaries who speak English, and we don't really need to speak ${ }^{(9)}$.

This commercial configuration, which hinges around anchorage and mobility and which is reactivating the old functions of hospitality, is not new in the world of African commerce and has been extensively explored in Africa and on other continents. The njaatigue (a "host" in the bambara language), this landlord and intermediary, facilitates relations between the traders. Not only does he provide lodging and the representation of the nomadic merchants before the administrative authorities, but he also acts as a guarantor among buyers and sellers and sometimes even takes on the responsibility of book-keeping for some merchants or interpreting services for others (Bredeloup, 2007). The traffic in gems conducted by the West African merchants has been able to develop precisely thanks to this figure, who has become the cornerstone of the diamond trade system.

The extreme porosity that exists between these types of migrants translates well the inanity of borders that are too often presented as impassable. Like the migrant identities, the migratory and market networks are just as fluctuating. The marketplaces reconstitute themselves according to the whims of economic and political events.

\section{Dubai, Bangkok, Jakarta, Hong Kong, Guangzhou: reconstituted marketplaces}

The entrepreneurs of sub-Saharan Africa, who contributed to making Dubai ${ }^{(10)}$ a major marketplace, started reconsidering their strategies once the "Asian tigers" (II), such as
Thailand and Indonesia, also embarked on a dynamic of competitive production. African traffickers of semi-precious stones already incorporated Bangkok in their transnational trading (Bredeloup, 2007) a long time ago and were able at that time to explore the potential that the city has to offer. On top of the transport and travel services available (facilities for obtaining visas, competitive air freight rates), the Thai capital is in fact home to a nursery of small highly capable enterprises capable of reproducing identically the models presented to them. The auto and textile industries are solidly established in the country. What's more, the cheap and compliant workforce allows products to be obtained at very competitive costs. At the end of the 1980s, African merchants, old traders in precious stones or import-export specialists, began to set up trading posts there. Thus they went door-to-door to local factories to have T-shirts, cosmetics and imitation pagnes produced for the West African markets, rerouting their trading circuits between Africa and Asia. A number of them, Malians, Guineans but also Nigerians, thus reproduced in Japan and South Korea the system that they had already tested out for a while. Thailand is regarded as an open country that has for a long time been able to weave ties overseas.

Considered a secondary market on the African routes because it offers some quite specific products (shoes and synthetic fabrics) of a higher quality and at somewhat higher prices, the trading post of Jakarta also mobilised some sub-Saharan merchants in the middle of the 1990s, before they were quickly redirected to Hong Kong, the gateway to mainland China. The Indonesian capital lost its appeal when foreign and, in particular, Chinese merchants were chased out of Jakarta in May 1998 (Izraelewicz, 2005).

Today, all roads seem to lead to Hong Kong: the traffickers in semi-precious stones who connected Bangkok to Hong Kong have thus been joined by the merchants who abandoned Jakarta or by those who wanted to adventure beyond Dubai. Despite its reintegration in 1997 into the People's Republic of China, Hong Kong remains a "useful airlock" through which transit the majority of international enterprises seeking access to the Chinese market. It constitutes a cru-

9. Interview with H.B., op. cit..

10. The city-state of Dubai is regarded as one of the best stocked "supermarkets" on a global scale, redistributing products manufactured in Europe as well as in Asia (Marchal, 2001; Battegay, 2005). Furthermore, since 2003, China has become the leading supplier of the Emirate.

11. A distinction is made between the "dragons" (Taiwan, Singapore, Hong Kong and South Korea) and the "tigers" (Indonesia, Malaysia, the Philippines and Thailand), the former taking off between 1970 and 1980 and the latter only from 1990 onwards. 
(1)

$\geq \quad$ cial financial centre and, especially well equipped in terms of transport, it re-exports a sizeable part of Chinese production, in spite of the competition from Shanghai. The first African to set up shop in Hong Kong was a Malian; he started trading in gold and precious stones in 1979 before having a go a few years later at the import-export business. However, the conditions for exercising this role are less supple than in Dubai, Jakarta or Bangkok. In the context of unbridled competition, only the few African traders possessing significant capital and social contacts have been able to open an office in Asia's business capital.

Since mainland China opened its doors, acceding in December 2001 to the World Trade Organisation, the commercial network has evolved still further. This integration of China in the world economy, following more than fifteen years of negotiations, offers new outlets that numerous African traders have not failed to seize upon. The majority of them who were established in Jakarta and Bangkok have grabbed the opportunity presented by this opening-up to set up an office in Guangzhou while sometimes maintaining their Indonesian and Thai branches, and while the few traders solidly anchored in Hong Kong only had to extend their trading networks to mainland China. The latter have thus profited from the creation of the four special economic zones $^{(12)}$ in southern China (Shenzhen, Zhuhai, Shantou and Xiamen) and of the unprecedented delocalisation to these places of Hong Kong enterprises who aimed to take good advantage of the various tax exemptions granted by the Chinese state at the end of the 1980s. This is how, following the examples of the large distribution companies, they started to visit the factories producing textiles, electronics and toys that proliferated in the Shenzhen zone in close proximity to Guangzhou. They then began to ink contracts with industrial partners, suggest new prototypes and monitor the sometimes defective manufacture.

On a more global scale, two movements can be perceived among the African merchants: whether they arrive directly from sub-Saharan Africa or whether they stopped off at another trading post in Southeast Asia, the "nomads" are in increasing numbers incorporating the marketplaces of Hong Kong and Guangzhou in their circuit, while traders are establishing themselves in force in the capital of Guangdong:

In Guangzhou now, there are around 100 offices maintained by Malians. The Guineans have more. In sum, it's difficult. Here there are three buildings and everywhere is full. That makes hundreds of
Africans. There are also some Congolese from the $R D C$, there are more of them than there are Senegalese ${ }^{(13)}$.

But this craze also has its limits. Setting up in Guangzhou remains under the strict control of the Chinese government, and disenchantment is growing:

People believed that China, it was going to be easy, that they were going to get everything, and then all of a sudden they saw the difficulties (...) In December 2006, there was supposed to be a total opening-up: up to now, services like the banks, for example, have been a closed sector for foreigners (...) Trading is still very limited for foreigners. It is easier to open a factory than to do business in China (...). It is the big African businesspeople who can get the capital that's needed; some Senegalese have a factory for producing real wax in a province next to Shanghai and they have set up their office in Guangzhou, nearby, in another building ${ }^{(14)}$.

Apart from the administrative difficulties that endure in China, the quality of the goods produced still leaves something to be desired:

In Canton, the products are much less expensive, they are manufactured in small factories that aren't accredited, there may even be some broken equipment, not well finished (...) Here, the major problem, it's the quality: people look for the best price possible but often they get back goods of poor quality, damaged goods. Women's shoes here, that takes three days. Buyers have lost money with some containers that, once they've been unloaded, hold the surprise that they contain products where $80 \%$ don't work. Then, you're sunk! If you negotiate too low, the vendor will change the quality of the items, for example for computers they change the copper for cheaper materials; even for bags, they'll change the zip, they'll put in one of worse quality, so once it's been opened and closed a few times, it breaks. If you don't know how to verify, you'll get taken for

12. These four zones were created on the initiative of Deng Xiaoping in 1978

13. Interview with P.B., Congolese merchant, Guangzhou, July 12 th 2006.

14. Interview with J. B., Ghanaian merchant, Guangzhou, July 11 th 2006. 
a ride. When you buy in China, you really have to know your product. You can get good quality there if you're prepared to pay for it. In China, it's the ground floor of production ${ }^{(15)}$.

This situation explains why the African merchants maintain part of their activity in the other trading and supply posts, playing on the comparative advantages. In contrast to Hong Kong in particular, Guangzhou's port infrastructure, which sprawls along the Pearl River, cannot receive the big container ships.

Guangzhou, it's a small port and it goes out through Hong Kong. From Guangzhou, you use feeders ${ }^{(16)}$, which only have a certain capacity; once they've arrived at a large port in Asia, there's a change of ship, they take bigger volumes. Some of Asia's big ports go directly to Africa, such as Shenzhen, Singapore, Ningbo Beilun ${ }^{(17)}$ and Hong Kong ${ }^{(18)}$.

Not only do the African merchants make a contribution to the economic development of the host country, both as employers and as taxpayers, but they are also playing a part in the transformation of the districts in which they work and lodge. The following section looks at the way in which they have integrated into Chungking Mansions in Tsim Sha Tsui in Hong Kong or even the way in which they occupy the tower blocks of the district of Xiao Beilu in Guangzhou. In these spaces, do they pick up the reins from other communities or do they even allow value to be added to vacant sites?

\section{Setting up a trading post in a Chinese city}

\section{What future for Chungking Mansions in Hong Kong: African tower of Babel or part of a new central business district?}

In Hong Kong, in the "kingdom of merchants" (Le Corre, 1997), the entrepreneurs from sub-Saharan Africa are concentrated principally in the district of Tsim Sha Tsui (on Nathan Road) on the Kowloon peninsula, after the pioneers occupied the district of Mong Kok. In 2006, several hundred reside or do business in Chungking Mansions, this degraded urban island, considered to be one of the least safe points in the city. Strongly stigmatised in the tourist guides and the local press, Chungking Mansions has by turns been called "immense dilapidated slums welcoming all the outcasts of the planet", "a sanctum for illegal immigrants, prostitutes from the Indian sub-continent", a place that draws together "dodgy merchants, discreet tailors' workshops and empty jewellery shops (but used all the same)", a "hold-out for drug traffickers and criminals". At the time it was constructed in 1961, Chungking Mansions was a residential development, predominantly welcoming Chinese from Canton, along an artery where hotels and luxury boutiques alternated with each other. Currently, the Mansions, which house on 17 storeys hundreds of guesthouses alongside import-export centres, exchange bureaus, Internet cafés, travel agencies, shops, dressmaking workshops, ivory and stonecutting shops and ethnic restaurants, is said to constitute a real "African tower of Babel" (Bodomo, 2005). The contrast between the goods sold in the Mansions' shopping arcades and the brand-name clothing, perfumery and hi-fi products offered in the luxury boutiques outside on Nathan Road is striking. Several hundreds of clients from the four corners of the black continent come to stock up each week on cheap products from their compatriots but also from merchants originally from the Middle East, Nepal, Sri Lanka, Bangladesh and above all India and Pakistan ${ }^{(19)}$. Despite the linguistic diversity, it would seem that merchants and clients alike have found not only unifying languages in which to do business (Bodomo, 2006) but favourable working conditions in this trading post.

A legendary stopover for backpackers and those on a small budget, Chungking Mansions offers, through the intermediary of touts, sometimes windowless rooms (blind walls) at very competitive prices for travelling African merchants. The whole building is made up of five blocks, access to each of which is granted by two lifts. At the end of the day, long queues of clients staying at the guesthouses form at the entrance to these antediluvian lifts that only hold a few people. It is a dangerous place in so far as fires frequently break out. The emergency exits are often blocked and the few lifts with their limited capacity often break down. And finally, Chungking Mansions is a place that has been made mythi-

15. Interview with A.D., Senegalese merchant, Guangzhou, July 12 th 2006.

16. A feeder is a ship of small tonnage that allows a cargo brought into a major port on a container ship that makes few calls to be distributed to different ports. Going the other way, the feeder can collect merchandise to be consolidated at the major port.

17. Ningbo is a coastal city south of Shanghai that hosts the port of Beilun, one of China's four deepwater, international transit ports.

18. Interview with A.B., Cameroonian merchant, Hong Kong, July 13th 2006.

19. In 1996, before the handover, records showed 22,000 Indians (part of the heritage of the British Empire) (Lau, 1996). 
cal by film-makers, especially by Wong Kar-Wai in his films Chungking Express and Fallen Angels.

Despite the large-scale reclamation works that have been carried out in Hong Kong over the last several decades, its population density remains one of the highest in the world. The pressure on land compels policies of urban renewal to be implemented. Thus the neighbourhood in which Chungking Mansions is located, on the southern tip of the Kowloon peninsula, very close to the Star Ferry pier, facing Hong Kong island and directly across the harbour from the central business district, lies at the heart of the urban planning stakes. In fact, since the new airport was built in 1998 at Chek Lap Kok on Lantau Island, replacing the previous one at Kai Tak located in Kowloon Bay, the regulations that prohibited the height of constructions on Nathan Road for safety reasons have now become obsolete. It is a time for speculation in the Chungking Mansions area. Some neighbouring buildings have already been subject to rehabilitation, while others, covered in immense green tarpaulins and advertisements announcing the city of tomorrow (Coming Soon: A New Centre of City Life), are in the process of renewal. According to the African exporters encountered, the level of degradation of Chungking Mansions is such that the destruction of the buildings is the only possible option. In these conditions, the owners no longer maintain their properties at all, nor the communal spaces and related facilities, hoping instead to receive substantial compensation when renovation works are started. This raises the question of whether the foreign merchants will have the means to keep up their activity in a rehabilitated district with direct links to Hong Kong's international transport infrastructure. Or will they be able to transform this new constraint into an opportunity and invest in other places in Hong Kong, in mainland China or elsewhere in Asia that offer services and facilities more in tune with their transnational trading?

\section{The Xiao Beilu district in Guangzhou: an African enclave under surveillance?}

According to our investigations, the first merchant from subSaharan Africa a Malian national is said to have opened an office, in 2000, in Guangzhou in the district of Xiao Beilu two years after having conducted initial prospecting in the capital of Guangdong.

I was the first to set up in Guangzhou, the first arrival in this building. The government said to me: 'it's necessary to establish yourself in a secured building to have papers'. I met the manager here at Tianxiu Building, and he, he made the contract. It was that, to get the papers, you had to have a contract ${ }^{(20)}$.

Under the pretext of security, the African merchants who move into this tower block are subject to permanent control by officers of the security forces, a control for which they, paradoxically, are obliged to bear the financial costs:

Tianxiu Building, a modern 35-storey building, is located in the northwest of the city, close to the central railway station, on a very busy main road, Huanshi Middle Road, in an island of tower blocks. As soon as the visitor arrives in this district, he is struck by the African presence. Small groups of men, originally from sub-Saharan Africa, move from one tower block to another using the overhead footbridges, while others hail taxis from the pavement or stand around talking at the entrance to Tianxiu Building. Some are dressed down, in jeans and polo shirts with a backpack; others wear suits, attaché case in hand. The activity at the entrances to these tower blocks seems intense. Some "matrons" in boubous call to each other across the pavements before going off to prepare rice and fish in small, secret "greasy spoons" that they run on the upper floors of Tianxiu or Guolong Building. Younger women, dressed Western-style, meet up in the areas where the export goods are displayed. If one is to believe the Africans themselves, sticking together with one's own remains a must in a Chinese society that is foreign to them:

Here there are African families, parents with children. The babies are there, they go to kindergartens, when they are older they go back to Africa (...) We Africans, we haven't got used to Chinese cuisine. Many of the African women have done African cooking, some do deliveries to the office, to the upper floors. The Chinese authorities haven't wanted the African women to open restaurants; they exist but they are hush-hush ${ }^{(21)}$.

The exercise of control by the public authorities also extends to questions of religion: the foreigner is only tolerated in China and has a duty to avoid any gathering, comparable to possible subversion as soon as it exercises any activity that is not commercial.

On the seventh floor of the building, some Africans had got themselves organised to open a mosque; there was also an

20. Interview with D.D., op. cit..

21. Interview with H.B., op. cit.. 
Adventist church there. The Chinese authorities came and closed everything. You try to get the embassies to intervene when there is a problem, but they are not on site and then for everything to do with religion, you have to let it go. Here, the problem is that there's no possibility of association: any gathering is looked on as suspect, as a risk for the Chinese government. If you understand that, here, it's only for business, it's $O K^{(22)}$.

Fearing that they cannot grasp all the complexities of the regulatory system established by Chinese society, a system that is itself in a perpetual process of redefinition, the African merchants, to protect themselves and to conform, opt for discretion in the tower blocks and in the neighbouring streets and limit their social contacts to their compatriots.

On the ground floor of the Tianxiu tower block, two entrances: the main gate allows direct access to the commercial services. The Lounge Coffee and the Moka Café, run by Chinese staff, have become the meeting-points for the African merchants doing business. At the exit, an Internet area, doubling up as a travel agency, offers its facilities to the traders working there. A few feet away, the sign of a cargo transport company lights up the destinations Dubai, Sharjah (United Arab Emirates), Jeddah (Saudi Arabia), Aqaba (Jordan's only maritime outlet), Douala (Cameroon), Lagos (Nigeria), Pointe-Noire (People's Republic of Congo) and Matadi (Democratic Republic of the Congo). This service, offered in the confines of the same building, allows merchants who are pressed for time to gain some efficiency in their comings and goings. On the four upper floors, access to which is granted both by elevators and escalators, samples of merchandise, exportable especially to the African continent, are piled up in almost 350 shops, each about twelve square metres, spread through a maze of corridors. The majority of the exhibitors are Chinese, although Africans, of both sexes, are tending gradually to occupy the premises.

(...) There has been a kind of partition of the building between the Africans and the Chinese (...) The Africans have started occupying some offices on the upper floors; they have attracted a certain clientele. The Chinese have seen all that and they have come and occupied the lower floors. These Chinese are representatives of factories who have wanted to profit from the clients of the Africans who go up the floors to get to the offices on the 7th and 9th floors.

Within the framework of this new distribution, for two years now, $\mathrm{Mr} \mathrm{F}^{(23)}$, a Ghanaian national, displays shirts, blouses, T-shirts, jeans, Terylene trousers, plastic sandals, sports shoes, washing powders, nappies, handbags, umbrellas, wheeled suitcases, bikes, mopeds and more, chaotically, in his glass-fronted premises on the fourth floor. Behind his computer, her Ugandan partner once again updates on the Internet their homepage so as to present the new items to potential clients. Buyers from all over Africa do the rounds of these floors.

The other entrance to the building, which leads directly via lifts to the upper floors where the offices are located, is under the double surveillance of guards and cameras. Ears glued to their mobile phones, chatting away in English, in French, in soninke or even in Swahili, the "visitors" stationed in front of the doors to the lifts are all, without exception, Africans. Starting from the fifth floor, this is the empire of the African traders, who display their merchandise in spacious show rooms:

Here, before, there were a lot of empty offices (...)

When the Africans arrived in the tower, the Arabs left; they still have restaurants, cafés here ${ }^{(24)}$.

If the Arab merchants established in Guangzhou have abandoned Tianxiu Building, relocating to other buildings on the same or a neighbouring island, the Arab clientele continues to frequent the tower and, in particular, to conduct their business in the cafés on the ground floor. The African trading companies share the upper floors offering, in apartments of around 150 square metres reconfigured as office and sales space, an incalculable number of recommendations. Just to take one example, an inventory conducted at Mr D's, in the room dedicated to household appliances, revealed: potato mashers, juicers, food mixers, hair-dryers, irons, electric toothbrushes. In another room, a multitude of samples of household goods (office, bedside and garden lamps, door locks, ironing boards, scales, china and plastic crockery) fill shelves and tables, alongside food products (tea bags, oil, rice, tinned food) and toys. Clothes, shoes and bags as well as televisions and hi-fi equipment are all concentrated in a third room. Finally, a last room collects on clothes racks copies of African pagnes, from wax to basins (damask fabric) and embroidery. In addition to placing his order, the client can in this space, both cosy and high tech at the same time, make use of the Internet, book air tickets, carry out customs procedures for the purchased products and take advantage of consolidation operations.

22. Interview with S.N., Togolese merchant, July 9th 2006.

23. Interview with P.F., Ghanaian merchant, Guangzhou, July 11th 2006.

24. Interview with A.K., Malian merchant, Guangzhou, July 11 th 2006. 


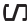

The contrast is thus striking between the towers where the activity is structured exclusively around trade according to the logic of the trading centre and where a homogenous population with shared objectives comes together, under strict surveillance, and the exterior of the buildings. In the streets, Cantonese at work criss-cross with Africans waiting for a taxi, while Chinese beggars grab positions attracted by the imagined riches that transit through this new economic focal point. The Africans encountered talk of compatriots who are said to have been recent victims of aggression and affirm at the same time that identity checks on the sub-Saharan communities have been stepped up. The evidence suggests that their visibility is growing in Xiao Beilu, where new arrivals are coming to join their compatriots who have already established themselves. Everyone now knows that money circulates in this hotbed of international trade. Is there not a risk, in the long term, that the insecurity suffered by the Africans, which already seems a reality, will be amalgamated with the staging of an insecurity, linked to the African presence, that can already be seen to be burgeoning ${ }^{(25)}$ ? Some have come up with the hypothesis that the forthcoming arrival of the metro ${ }^{(26)}$ in the district, which should see its land values rise and prompt its re-designation, could well spur the local Chinese authorities into using this argument to justify their urban planning interventions.

\section{In conclusion}

While China, under cover of the "win-win" ideology, is multiplying its economic agreements with the countries of Africa, with their wealth of hydrocarbons and other natural resources, and offering its cheap consumer products for the mass market, the African merchants, for their part, are extending to China their transnational networks that they have woven for a long time now. In a way similar to the first colonists, these businessmen from sub-Saharan Africa are exporting their experience and abilities to unknown shores as they establish themselves there. They are creating trading posts in the cities of Hong Kong and Guangzhou and benefiting from the services offered by the local, regional and national authorities. At the opportune moment, even before China's accession to the WTO, they tapped in these trading places products manufactured in the hinterland to fulfil the demand of their African clientele. Trading post or reverse trading post? On the evidence we have seen, and all things being relative, it cannot be concluded that these African merchants are colonising China even if they are participating, from the bottom up, in the animation of certain business districts. If Hong Kong seemed to them, for an initial period, an open city, more internationally anchored and offering a liberal, less restrictive framework, Guangzhou has gradually tempted them thanks to its proximity to the production sites located essentially in free zones. But today, the factories are not only gearing down but are also being established in other regions of China. From now on, textiles will be produced in the inland Chinese provinces, and Shenzhen is being transformed into a gigantic specialised workshop for the manufacture of televisions, computers and electronic game consoles. African merchants have already spread out to the south of Shanghai, to the city of Yiwu (Pliez, 2007) which is regarded as the new "supermarket of ChinaAfrica" (27). In Guangzhou, regulations are slow to loosen up with regard to foreign merchants, who cannot import merchandise nor benefit, as a whole, from the support of the local banking structures. On the other hand, despite the efforts dedicated by the Chinese government to modernising the transport infrastructures, both the airport and port of Guangzhou will need time to be able to rival those of Hong Kong. This context undermines the role of Guangzhou in the merchant mechanism structured by the Africans as it undermines the inclusion of these foreign merchants in the city. If some envisage a retreat to Hong Kong or a new departure to far more promising places particularly in the province of Zhejiang (Guiheux, 2007) or even to the more southern countries of Asia, others are striving hard to legitimise and add value to their presence in Guangzhou, planning in particular to create an African business association. In this context of rapid restructuring, where the Chinese cities may find themselves in competition, the local public authorities will be forced to improve the conditions under which they offer a reception to their commercial guests. •

\section{- Translated by Nick Oates}

25. In the interviews conducted with Chinese intermediaries, xenophobia is a recurring theme. Either those interviewed themselves hold racist views on the practices of their employers, which they did not spell out in so many words but for which they sought our complicity and support, or they report comparable xenophobic remarks expressed, in other circumstances, by their Chinese compatriots.

26. The Guangzhou metro came into service in 1999. It currently has four lines.

27. "Yiwu, le supermarché de la Chine-Afrique", M. Sztanke, A. Lewkowicz and P.-L. Lacombe, ARTE GEIE / Ligne de Mire Production, France, 2006; cf. also the article by Yue Lin (2006). 


\section{Bibliography}

Marc Aicardi de Saint-Paul, "La Chine et l'Afrique, entre engagement et intérêt", géopolitique africaine, no. 14, Paris, 2004, 9 pp.

Alain Battegay, "Dubai, économie marchande et carrefour migratoire. Étude de mise en dispositif", in Hana Jaber, France Metral (eds.), Mondes en mouvements. Migrants et migrations au Moyen-Orient au tournant du $21^{\mathrm{em} e}$ siècle, IFPO, Beirut, 2005.

Brigitte Bertoncello, Sylvie Bredeloup, "La migration chinoise en Afrique: accélérateur du développement ou sanglot de l'homme noir?", Afrique contemporaine (2), no. 218, 2006, pp. 199-224.

Adams B. Bodomo, "An emerging African-Chinese community in Hong Kong: the case of Tsim Shua Tsui’s Chungking Mansions", Conference on Afro-Chinese relations: past, present and future, Johannesburg, November 23rd-25th 2005.

Adams B. Bodomo, "Cultural and linguistic parallels between Africa and China: the case of some West African and Southern Chinese societies", paper read at the 3rd roundtable discussion on African studies, University of Hong Kong, May 25th 2006.

P.-Antoine Braud, "La Chine en Afrique, anatomie d'une nouvelle stratégie chinoise", Analysis, October 2005, 7 pp.

Sylvie Bredeloup, La Diams'pora du fleuve Sénégal, to be co-published in 2007 by PUM Toulouse / IRD, Paris.

Jean-Raphaël Chaponnière, "Les échanges entre la Chine et l'Afrique. Situation actuelle, perspectives et sources pour l'analyse", STATECO, no. 100, 2006, pp. 149-162.

Jean Coussy, "Idéologies, diplomaties et intérêts dans les relations économiques afro-asiatiques", Politique africaine, no. 76, December 1999, pp. 47-62.

Gregor Dobler, "South-South business relations in practice: Chinese merchants in Oshikango, Namibia" (draft version, September 2005), 2005.

Elame Esoh, "L'immigration en Afrique Noire dans le contexte de la mondialisation"(www.lestamp.com/publications mondialisation/public ations.esoh.htm), 2005.

Catherine Fournet-Guérin, "La nouvelle immigration chinoise à Tananarive (Madagascar)", Perspectives chinoises, 2006, no. 90, 2006.
Adama Gaye, Chine-Afrique: le dragon et l'autruche, Paris, L'Harmattan, 2006.

Emmanuel Grégoire, Pascal Labazée, (eds.), Grands commerçants d'Afrique de l'Ouest. Logiques et pratiques d'un groupe d'hommes d'affaires contemporains, Paris, ORSTOM-Karthala, 1993, 262 pp.

Gilles Guiheux, "Sociologie historique des marchés de gros de Yiwu (province du Zhejiang)", Communication EHESS, Mondes patronaux et territoires, Paris, January 2007.

Heidi Haugen \& Jørgen Carling, "On the Edge of the Chinese Diaspora: The Surge of Baihuo Business in an African City", Ethnic and Racial Studies 28(4), 2005, pp. 639-662.

Nathalie Hoffmann, Christophe Mabire, Afrique-Asie, vers un nouveau partenariat, Paris, CHEAM, La Documentation Française, 2000.

Erik lzraelewicz,. Quand la Chine change le monde, Paris, Grasset \& Fasquelle, 2005, 284 pp.

Eglantine Jastrabsky, "Le poids de Canton", Outre-Terre, no. 15, 2006/2, pp. 161-177.

François Lafargue, "La Chine, une puissance africaine", Perspectives Chinoises, no. 90, July-August, 2005, pp. 2-10.

Caroline Lau, Hong Kong, Paris, CFCE, 1996.

Philippe Le Corre, "Après Hong Kong. Chinois et cosmopolitisme: un pays, deux systèmes?" Autrement, January 1997, 280 pp.

Yie Lun, "Yiwu: le carrefour du 'made in China", Outre-Terre, no. 15, 2006/2, pp. 187-193.

Roland Marchal (ed.), Dubaï, cité globale, Paris, CNRS, 2001.

Valérie Niquet, "La stratégie africaine de la Chine", Politique étrangère, no. 2, 2006, pp. 361-374.

Olivier Pliez, "Du Sa id à Yiwu, les territoires invisibles des commerçants et migrants égyptiens", CEPED seminar on "Mobilités, migrations internationales: impacts sociaux et territoriaux", February lst 2007.

Alain Tarrius, "Naissance d'une colonie: un comptoir commercial à Marseille", Revue Européenne des Migrations Internationales, vol. 11, 1995, pp. $21-52$. 